\title{
Comparative studies on insect species of cowpea (Vigna unguiculata) (L) walp in two agro-ecological zones during the early cropping season, in Delta State, Southern Nigeria
}

\author{
E.O. Egho \\ Department of Agronomy, Faculty of Agriculture, Delta State University, Abraka \\ ABSTRACT
}

The study took place during the early planting season of 2005, in Asaba and Abraka, both in Delta State, Southern Nigeria. Asaba occupies the drier northern part of the state while Abraka, in the south, experiences a more humid weather. Insect species that decimate cowpea (Vigna unguiculata (L.) Walp in both locations, about 135 kilometres apart were identified and compared. The results showed that the occurrence and distribution of insect species followed different trends. Asaba recorded 10 insect orders, 34 families and 50 species, compared to Abraka with 8 orders, 25 families and 37 species in the same season. The dominant species in both locations were coleoptera. Asaba recorded slightly more coleoptera, heteroptera, diptera, hymenoptera and lepidoptera than Abraka. Conversely, there were slightly more orthoptera than Asaba. Ootheca mutabilis Sahl, Aphis craccivora Koch, Megalurothrips sjostedti Tryb, Maruca vitrata Fab, and coreid bugs such as Cravigralla tomentosicollis Stal, Anoplocnemis curvipes Fab, C. shadabi Doll, Aspavia armigara Fab, Nezara virudula L, Mirperus jaculus Thnb were the commonest major insect pests on cowpea at Asaba and Abraka. More insect species occurred at Asaba than Abraka in the early season.

Keywords: Cowpea, insect pests, early season, Asaba/Abraka, southern Nigeria.

\section{INTRODUCTION}

Cowpea (Vigna unguicalata (L.) Walp) is a legume of the family Fabaceae. Many human communities in Africa rely on it as cheap source of protein (IITA, 1984), more so when protein derived from fish, meat, milk and eggs have gone out of the reach of the poor man. It has been described as the poor man's meat (Aykyord and Doughty, 1982). The grains are consumed in various forms - as boiled grains mixed with other food spices. The crop is important in soil erosion control (Okigbo, 1978) fibre production (Rachie, 1985) restoration of soil fertility and livestock industries (Job et al., 1983).

Cowpea is grown in the tropical and sub-tropical regions of the world. In Nigeria, it is grown mainly in the drier regions of Northern Nigeria, though recently the cultivation has gained ground in Southern Nigeria, in the West and East (Ejiga, 1979; FOS, 1995; Emosairue et. al., 2004). Insect pests have been clearly identified, among other factors, as major constraints in cowpea cultivation (Taylor, 1964). The major insect pests reported on cowpea to cause severe damage in the field are the foliage beetle,
Ootheca mutabilis Sahl, the cowpea aphid, Aphis craccivora Koch, the flower bud thrips, Megalurothrips sjostedti Tryomb, the legume pod borer, Maruca vitrata Fab and a host of pod sucking bugs which include Clavigralla tomentosicollis Stal, Anoplocnemis curvipes Fab, Aspavia armigera Fab. From seedling to harvest phase, cowpea is under perpetual siege. Apart from the direct damage to the crop, some of the insect pests such as Aphis craccivora and Ootheca mutabilis cause indirect injury to the crop, by transmitting viruses which further worsen the crop condition (Singh and ven Emden, 1979). Wherever the crop is cultivated, insect pests are known to attack it. However, insects vary from locality to locality, i.e. not all insects occur in all regions (Singh and Jackai, 1985). The activities of insect pests have greatly contributed to the low yields of cowpea in African countries and control of cowpea pests has largely been by the application of synthetic chemicals (Jackai, 1993).

This work attempts to study the insect species of cowpea in two widely located agro-ecological zones (135 kilometres apart) in Delta State, Southern Nigeria, during the early planting season, 2005. It reports their insect species, the differences and similarities of species in the localities. 


\section{MATERIALS AND METHODS}

Studies on the insect complex of cowpea in the early planting season were carried out in two agroecological zones - Asaba and Abraka both in the rain forest zone, Delta state Nigeria. The locations are about 135 kilometres apart. Asaba lies in the Northern part of the state, with drier climate condition while Abraka is located southward and closer to the riverine area of Delta State.

The experiments were conducted in Asaba in the Teaching and Research Farms of the Agronomy department of the campus of the Delta state University. At Abraka, the experiment took place on a public land half a kilometre to the main campus of Delta State University. At Asaba the land was ploughed and harrowed while at Abraka, the land was manually prepared with shovels and hoes. Experimental Plot size for cowpea was $5 \mathrm{~m} \times 3 \mathrm{~m}$ with $1.5 \mathrm{~m}$ in between plots. Ife brown cowpea seeds were planted in the plots at planting spacing of $30 \mathrm{~cm}$ and $60 \mathrm{~cm}$ (Remison, 1978e). Planting took place in Asaba on May 28th 2005 and June 14th 2005 in Abraka. Three seeds were planted per hole and seeds that did not germinate were replaced. Thinning to two per stand was done, ten days after seed emergence. Each cowpea plot contained 6 rows of 36 stands. The plots were kept weed free throughout the study period.

Insect collection commenced two weeks after planting and continued till harvest. Insects were collected weekly with a sweep net (diameter $30 \mathrm{~m} \times 75 \mathrm{~cm}$ ) between 8.00 a.m. and 10.00 a.m. Insects were also hand-picked. All insects collected were identified by the curators at the Institute of Tropical Agriculture (IITA) Ibadan, Nigeria and the Institute for Agricultural Research and Training (AIRT), Ahmadu Bello University, Zaria, Nigeria.

\section{RESULTS AND DISCUSSION}

A list of the insect species (insect complex) of cowpea during the early planting season at Asaba and Abraka is presented in Table 1. There were 10 insect orders, 34 families and 50 species at Asaba while eight (8) insect orders, 24 families and 37 species were encountered at Abraka in the same season. The insect order, number of species and their relative abundance (\%) in each locality are given in Tables 2 and 3 . The coleoptera, heteroptera, homoptera, hymenoptera and lepidoptera were slightly more in population at Asaba when compared with Abraka. Conversely, Abraka had more orthoptera than Asaba. Equal number of thysanoptera and diptera was encountered at both locations. The coleoptera were the most dominant species in the two locations. Both locations recorded 1 species each for thysanoptera and dermaptera to be the least dominant. Twenty (20) insect species which occurred at Asaba during the early season were absent at Abraka. These were Platyomicus sp., Hoplostomus fulgineus, Oliv, Lycus nr foliaceus Palm (Coleopterans), Geocoris sp., Coptosama stali Mort, Brachyplatys sp., Coptosoma nubila Germ, Cletomorpha lanciger Fab, Helopeltis schoutedeni Reut (Heteropterans), Scymnus scapuliferus Muls, Locris maculata culata Fab (Homopterans), Pseudocreobotra ocellata Pal, Opius sp., Halictus sp. Megaponera foetens Fab (Hymenopterans). Borbo zazzau Norman, Hymenia recurvalis Fab (Lepidopterans) Blattella loviventris Sau, Rhaphiophana nigrifrons Mel (Dictyopterans) and Chelisoches flavippenis (Dermaptera). Conversely, seven insect species recorded at Abraka in the early season were absent at Asaba. These were,

(i) Lema coelestina (coleoptera)

(ii) Septontia nitreas Lv (Heteroptera)

(iii) Mirperus jaculus Thunb (Heteroptera)

(iv) Clavigralla shadabi Dolling (Heteroptera)

(v) Phaneropter nana sparsa Stal (Orthoptera)

(vi) Mersamia trapezalis Geyer (Lepidoptera)

(vii) Orientostenaracus tripatitus (Hymenoptera)

This study confirmed the variability of insect species in different localities (Jackai, 1985). On the whole, there were more insect species in Asaba than Abraka. The major insect pests of cowpea reported from the main cowpea growing areas of Nigeria - the cowpea aphid Aphis craccivora Koch; the flower thrips, Megalurothrips sjostedti Tryb., the legume pod borer, Maruca vitrata Fab. and C. shadabi, Anoplocnemis curvipes, Mirperus species, Nizera virudula and Aspavia armigera (Libby, 1968, Singh and van Emden, 1979; Singh et al., 1983; Jackai, 1985; Jackai and Dauost, 1986; Ogunwolu and Ekefan, 1991) and from Umudike, Southern Nigeria (Emosairue et al., 2004) were observed in the study areas in the same season.

Results from these studies showed that $A$. craccivora occurred during the early season at both locations. However, more infestations occurred at Abraka when compared to Asaba - all plots were highly infested at Abraka (over 500 per stand in the two middle rows) two weeks after planting (2WAP). This high infestation level at Abraka, is indicative of the magnitude of damage to cowpea and its control would be required in the study area as $A$. craccivora has been reported to cause severe damage to seedling phase of cowpea (Attiri et al., 1984; Singh and Jackai, 1985; Roberts et al., 1993). Flower thrips occurred at both locations. However, they were slightly more at Asaba than Abraka. Similar observations were made for Maruca vitrata. The pod sucking bugs were generally low (1 bug/m row) and control of PSB infestation may not be necessary in the study areas during the early planting season. 
Agric. Biol. J. N. Am., 2010, 1(5): 946-949

Table 1: Insect species on cowpea in the early cropping season at Asaba and Abraka

\section{Asaba Locations}

\begin{tabular}{|c|c|c|c|c|c|}
\hline \multirow{5}{*}{$\begin{array}{c}\text { Order } \\
\text { Coleoptera } \\
\text { ", } \\
\text { ", }\end{array}$} & Family & Insect species & Insect species & Family & Order \\
\hline & Chrysomelidae & Ootheca bennigseni Weise & Ootheca bennigseni Weise & Chrysomelidae & Coleoptera \\
\hline & Chrysomelidae & Ootheca mutabilis Sahlberg & Ootheca mutabilis Sahlberg & Chrysomelidae & Coleoptera \\
\hline & Chrysomelidae & Medythia quarterna Fair & Medyethia quarterna Fair & Chrysomelidae & Coleoptera \\
\hline & Chrysomelidae & Cryptocephalus gladiatorius Suff & Cryptocephalus gladiatorius Suff & Chrysomelidae & Coleoptera \\
\hline & Curculionido & & Lema coelestina & Chrysomelidae & Coleoptera \\
\hline$"$ & Curculionidae & Platyomicus sp & & & \\
\hline ", & Curculionidae & Piezotrachelus sp. & Piezotrachelus sp & - & - \\
\hline ", & Scarabacidae & Hoplostomus ful'gineus (Oliv) & - & - & - \\
\hline \multirow{3}{*}{$"$} & Lycidae & Lycus nr foliaceus Palm & & & \\
\hline & Bruchidae & Callosobruchus maculatus F & Callosobruchus maculatus $\mathrm{F}$ & Bruchidae & Coleoptera \\
\hline & Ichneumonidae & Nematocerus acerbus (Fst) (Brulle) & Nematocerus acerbus (Fst) (Brulle) & Icheumonidae & Coleoptera \\
\hline ", & Lagridae & Lagria villosa Fab & Lagria villosa Fab & Lagridae & Coleoptera \\
\hline ," & $\begin{array}{l}\text { Coccinellidae } \\
\text { Meloidae }\end{array}$ & $\begin{array}{l}\text { Cheilomenes lunata Fab } \\
\text { Mvlabris so }\end{array}$ & Cheilomenes lunata Fab & Coccinellidae & Coleoptera \\
\hline \multirow[t]{2}{*}{ Heteroptera } & Miridae & Deraeocoris martina (Puton) & Deraeocoris martina (Puton) & Miridae & Heteroptera \\
\hline & Lygacidae & Geocoris sp & - & - & \\
\hline " & Plătaspidae & Coptosoma stali Mort & - & - & - \\
\hline \multirow{2}{*}{$"$} & Plataspidae & Brachyplatys sp & - & - & - \\
\hline & Plataspidae & Coptosoma núbila Germ & & & \\
\hline ", & Pyrhocoridae & Dysdercus superstitiosus F & Dysdercus superstitiosus F & Pyrhocoridae & - \\
\hline ,", & Coreidae & Cletomorpha lanciger Fab. & & & - \\
\hline ,", & Coreidae & Riptortus dentipes Fab. & - Rintortus dentines Fah & Coreidae & Eetorontera \\
\hline " & Pentatomidae & Aspavia armigara Fab & Aspavia armigara Fab & Coreidae & Heteroptera \\
\hline \multirow{2}{*}{$" "$} & Pentatomidae & Nezara virudula $(\mathrm{L})$ & Nezara virudula $\mathrm{L}$ & Pentatomidae & Heteroptera \\
\hline & & & $\begin{array}{l}\text { Clavigralla shadabi Dolling } \\
\text { Sepontia nitreas Lv }\end{array}$ & $\begin{array}{l}\text { Pentatomidae } \\
\text { Pentatomidae }\end{array}$ & Heteroptera \\
\hline
\end{tabular}

- indicates insect's absence

Table 2: Insect orders, number of species and relative abundance (\%) in the early season at Asaba

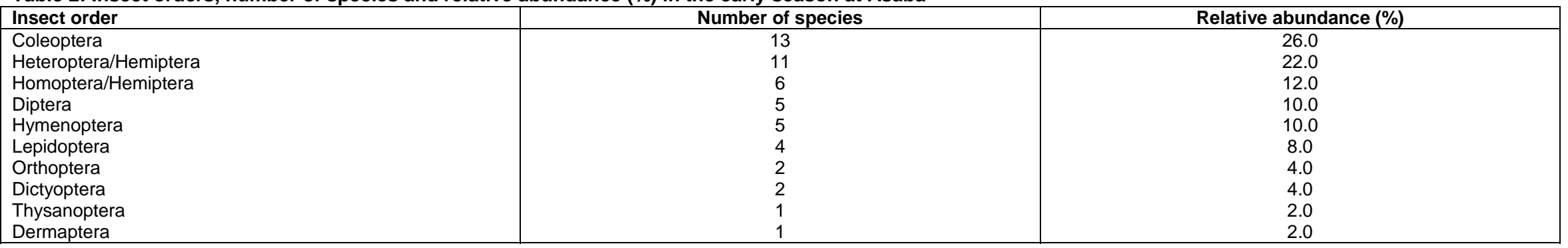


Table 3: Insect orders, number of species and relative abundance (\%) in the early season at Abraka

\begin{tabular}{|l|c|c|}
\hline Insect order & $\begin{array}{c}\text { Number of } \\
\text { species }\end{array}$ & $\begin{array}{c}\text { Relative } \\
\text { abundance } \\
\text { (\%) }\end{array}$ \\
\hline Coleoptera & 11 & 29.7 \\
Heteroptera/Hemiptera & 8 & 21.6 \\
Diptera & 5 & 13.5 \\
Homoptera/Hemiptera & 4 & 10.8 \\
Orthoptera & 3 & 8.1 \\
Hymenoptera & 3 & 8.1 \\
Lepidoptera & 2 & 5.4 \\
Thysanoptera & 1 & 2.7 \\
\end{tabular}

\section{CONCLUSION}

More insect species occurred at Asaba than Abraka in the early season. Ootheca mutabilis, Aphis craccivora, Megalurothrips sjostedti, Maruca vitrata and coreid bugs such as Cravigralla tomentosicollis, C. shadabi, Anoplocnemis curvipes, Aspavia armigara, Nezara virudula, Mirperus jaculus were the key insect pests identified in the areas. Coreid bug population was low at both locations and would not require control.

\section{ACKNOWLEDGEMENTS}

My thanks to the curators at the International Institute of Tropical Agriculture (IITA), Ibadan, Nigeria and Institute of Agricultural Research and Training (IART), Ahmadu Bello University, Zaria, Nigeria, who identified the insect species of cowpea from the study areas

\section{REFERENCES}

Atiri, G.I., E.J.A. Ekpo, and G. Thottappilly. (1984). The effect of aphid-resistance in cowpea on infestation and development of Aphis craccivora Koch and the transmission of cowpea aphid-borne mosaic virus. Annals of Applied Biology 104:339-346.

Aykroyd, W.R. and Doughty, J. (1982). Legumes in Human Nutrition. FAO. Nutrition Studies 19, FAO, Rome.

Ejiga, N.O. (1979) The efficiency of the indigenous food grain marketing systems in Nigeria, Savannah Dec., 8 (2), 70-83

Emosairue, S.O., G.E. Nwofia, S.B.A. Umuetok (2004). Observation on the Insect complex associated with cowpea (Vigna unguiculata (L.) Walk in Umudike, South-eastern Nigeria. J. Sustain. Agric. Environ. 6(1):38-43.

FOS (1995) Annual Abstract of statistics, Lagos, Nigeria.

IITA (1984) Annual Report for 1982. Ibadan, Nigeria
Jackai, L.E.N. (1985) Cowpea Entomology Research at IITA and its impact on food production in the tropics. Nigeria J. Ent. 6, 87-97

Jackai, L.E.N. (1993). The use of neem in controlling cowpea pests. IITA Research. No. 7, 5-11.

Jackai, L.E.N. and Daoust, R.A. (1986). Insect pests of cowpeas. Annual Review of Entomology 3195119

Job, T.A., Maner, J.H. and Buitrago,J. (1983) Nigerian J Nutr Sci, 4 (1), 29-34

Libby, J.L. (1968). Insect pests of Nigerian Crops. University of Wisconsin Res. Bull. No. 269:69pp.

Ogunwola, E,O. and Ekefan, E.J., (1991). Pod-sucking bug damage to cowpea in relation to time and frequency of insecticide application in the Southern Guinea Savanna zone of Nigeria. JAT Vol. 4 No. 2, 1-9.

Okigbo, B.N. (1978) Grain legumes in the agriculture of the tropics. In Pests of Grain legumes Ecology and control (Edited by Singh S.R. Van Emden H.E. and Taylor T.A) Academic Press, Inc., New York.

Rachie, K.O. (1985) Introduction. P. xxi xxviii. In: S.R. Singh and K.O. Rachie (eds). Cowpea research, production and utilization. Wiley New York.

Remison, S.U. (1978e) Cowpea agronomy works at National Cereals Research Institute. Paper presented at the 1st National meeting. On development of package. Recommendations for legume crops at N.C.R.I, Ibadan, 7-8 February.

Roberts, J.M.F., C.J. Hodgson, L.E.N. Jackai, G. Thottappilly and S.R. Singh, 1993. Interaction between two synthetic pyrethroids and the spread of two nonpersistent viruses in cowpea. Annals of Applied Biology 122:57-67.

Singh, S.R. and Jackai, L.E.N. (1985) Insect pests of cowpeas in Africa: their life cycle, economic importance and potential for control. Pages 217-231 in cowpea research production and utilization, edited by S.R. Singh and K.O. Rachie. John Wiley and Sons N.Y.

Singh, S.R. and van Emden, H.F. (1979) Insect pests of grain legumes. Annual Reviews of Entomology 24, pp. 255-278.

Singh, S.R. Singh, B.S., Jackai, L.E.N.and Mtare, B.R. (1983) Cowpea Research at IITA, IITA Inf. Ser. No. 14:20.

Taylor, T.A. (1964). The field pest problems on cowpea. (Vigna sinensis L.) in Southern Nigeria, Grower Producer 3 (2). 